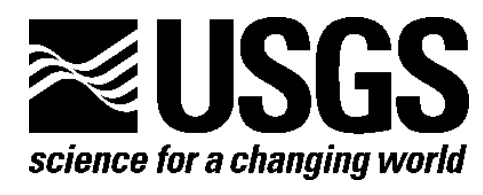

\title{
Laboratory and Field Tests of the Sutron RLR-0003-1 Water Level Sensor
}

By Janice M. Fulford and R. Scott Bryars

Open File Report 2014-1217

U.S. Department of the Interior

U.S. Geological Survey 


\section{U.S. Department of the Interior \\ SALLY JEWELL, Secretary}

\section{U.S. Geological Survey \\ Suzette M. Kimball, Acting Director}

U.S. Geological Survey, Reston, Virginia: 2014

For more information on the USGS-the Federal source for science about the Earth,

its natural and living resources, natural hazards, and the environment-visit

http://www.usgs.gov or call 1-888-ASK-USGS

For an overview of USGS information products, including maps, imagery, and publications, visit http://www.usgs.gov/pubprod

To order this and other USGS information products, visit http://store.usgs.gov

Suggested citation:

Fulford, J.M., and Bryars, R.S., 2015, Laboratory and field tests of the Sutron RLR-0003-1 water level sensor: U.S. Geological Survey Open-File Report 2014-1217, 20 p., http://dx.doi.org/10.3133/ofr20141217.

Any use of trade, firm, or product names is for descriptive purposes only and does not imply endorsement by the U.S. Government.

Although this information product, for the most part, is in the public domain, it also may contain copyrighted materials as noted in the text. Permission to reproduce copyrighted items must be secured from the copyright owner. 


\section{Contents}

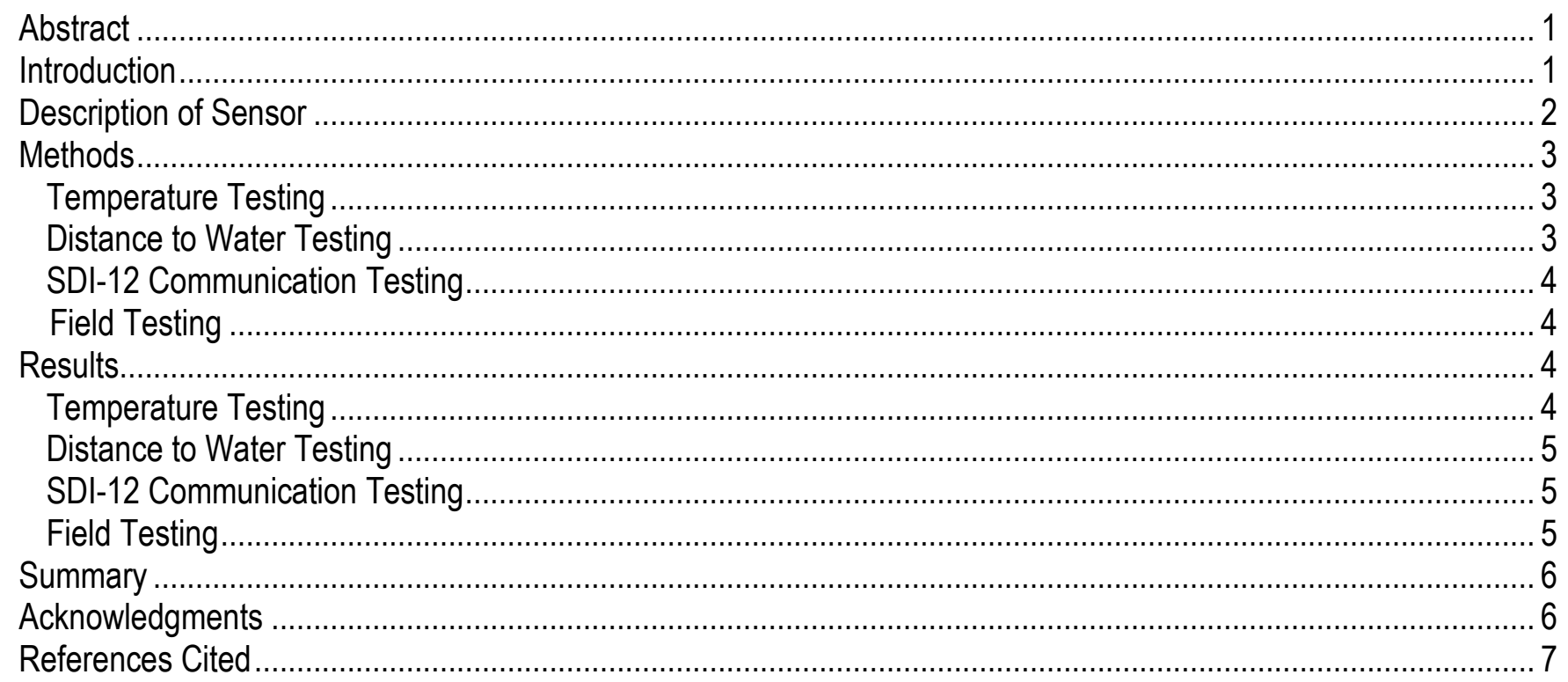

\section{Figures}

[Figures are located at back of report]

1. Photo of Sutron RLR-0003-1 water level sensor

2. Temperatures applied during temperature testing for three Sutron RLR-0003-1 water level sensors

3. Definition sketch of hydraulic laboratory test measurement variables

4. Air gap applied and water level measured during air gap testing for three Sutron RLR-0003-1 water level sensors

5. Difference between initial measured distance to a stationary target made by Sutron RLR-0003-1 (serial number 1208558) at room temperature and subsequent measurements made over temperatures from -40 to 60 degrees Celsius

6. Difference between initial measured distance to a stationary target made by Sutron RLR-0003-1 (serial number 1208559) at room temperature and subsequent measurements made over temperatures from -40 to 60 degrees Celsius

7. Difference between initial measured distance to a stationary target made by Sutron RLR-0003-1 (serial number 1208560) at room temperature and subsequent measurements made over temperatures from -40 to 60 degrees Celsius

8. Difference between the change in air gaps (distance to water) measured by Sutron RLR-0003-1 (serial number 1208558) and measured by the references

9. Difference between the change in air gaps (distance to water) measured by Sutron RLR-0003-1 (serial number 1208559) and measured by the references

10. Difference between the change in air gaps (distance to water) measured by Sutron RLR-0003-1 (serial number 1208560) and measured by the references

11. Differences between the Sutron RLR-0003-1 and the Sutron Accubar bubbler water level system readings (top chart) and differences between the Sutron RLR-0003-1 and the Design Analysis Associates (DAA) H3613 water level radar (bottom chart) at U.S. Geological Survey streamgaging site 06808500 , for the period February 28 to July 11,2013 
12. Comparison of the differences between the Sutron RLR-0003-1 radar, Design Analysis Associates (DAA) H3613 radar, and wire-weight gage readings plotted with U.S. Geological Survey Office of Surface Water (OSW) accuracy requirements

\section{Tables}

1. Manufacturer's specifications for the Sutron RLR-0003-1 water level sensor............................................ 2

2. Summary statistics for the difference between the Sutron RLR-0003-1 radar reading and the initial Sutron RLR-0003-1 radar reading at a stationary target for temperatures within 0.5 degrees Celsius of $-40,-20,0$, 20, 40, and 60 degrees Celsius for serial numbers 1208558, 1208559, and 1208560. Number of data points analyzed for each sensor was 898 .

3. Test 1 and test 2 summary statistics for the difference between the Sutron RLR-0003-1 radar difference with its initial reading and the reference difference with its initial reading.

4. Summary statistics for the differences between the Sutron RLR-0003-1 and either the Accubar bubbler system or the Design Analysis Associates (DAA) H3613 for the period of February 28 to July 11, 2013..... 6 


\section{Conversion Factors}

Inch/Pound to SI

\begin{tabular}{lcll}
\hline & Multiply & \multicolumn{1}{c}{ By } & To obtain \\
\hline & \multicolumn{2}{c}{ Length } \\
\hline inch (in.) & 2.54 & centimeter (cm) \\
inch (in.) & 25.4 & millimeter (mm) \\
foot (ft) & 0.3048 & meter (m) \\
\hline
\end{tabular}

Temperature in degrees Celsius $\left({ }^{\circ} \mathrm{C}\right)$ may be converted to degrees Fahrenheit $\left({ }^{\circ} \mathrm{F}\right)$ as follows:

${ }^{\circ} \mathrm{F}=\left(1.8 \times^{\circ} \mathrm{C}\right)+32$

Temperature in degrees Fahrenheit $\left({ }^{\circ} \mathrm{F}\right)$ may be converted to degrees Celsius $\left({ }^{\circ} \mathrm{C}\right)$ as follows:

${ }^{\circ} \mathrm{C}=\left({ }^{\circ} \mathrm{F}-32\right) / 1.8$ 


\title{
Laboratory and Field Tests of the Sutron RLR-0003-1 Water Level Sensor
}

\author{
By Janice M. Fulford and R. Scott Bryars
}

\begin{abstract}
Three Sutron RLR-0003-1 water level sensors were tested in laboratory conditions to evaluate the accuracy of the sensor over the manufacturer's specified operating temperature and distance-towater ranges. The sensor was also tested for compliance to SDI-12 communication protocol and in field conditions at a U.S. Geological Survey (USGS) streamgaging site. Laboratory results were compared to the manufacturer's accuracy specification for water level and to the USGS Office of Surface Water (OSW) policy requirement that water level sensors have a measurement uncertainty of no more than 0.01 foot or 0.20 percent of the indicated reading. Except for one sensor, the differences for the temperature testing were within 0.05 foot and the average measurements for the sensors were within the manufacturer's accuracy specification. Two of the three sensors were within the manufacturer's specified accuracy and met the USGS accuracy requirements for the laboratory distance to water testing. Three units passed a basic SDI-12 communication compliance test. Water level measurements made by the Sutron RLR-0003-1 during field testing agreed well with those made by the bubbler system and a Design Analysis Associates (DAA) H3613 radar, and they met the USGS accuracy requirements when compared to the wire-weight gage readings.
\end{abstract}

\section{Introduction}

The U.S. Geological Survey (USGS) Hydrologic Instrumentation Facility (HIF) evaluates the performance of hydrologic equipment and instruments used to measure, record, and transmit hydrologic data. These devices include sensors used to measure parameters needed to quantify streamflow, water quality, and groundwater levels, as well as devices used for data recording, data telemetry, water sampling, remote powering of equipment, and measurements from bridges and cableways. Performance is evaluated in a variety of ways and includes:

- the manufacturer's stated specifications for accuracy, resolution, and temperature operating range;

- any relevant USGS accuracy requirements;

and may include:

- compatibility with USGS field hydrologic data-collection communication protocols and infrastructure;

- the ability to operate unattended in field conditions; and

- power consumption. 
The evaluations may involve the deployment of the device at one or more field locations and usually involve testing in controlled laboratory conditions. Evaluations are primarily performed for determining if devices are suitable for use by USGS personnel for hydrologic data collection.

This report describes the methods followed and the results obtained from laboratory and field testing of a commercially available, noncontact, radar, water level measuring device, the Sutron RLR$0003-1$.

\section{Description of Sensor}

The Sutron RLR-0003-1 (fig. 1) is a water level sensor that uses radar to measure the distance between the sensor and the water surface. The sensor is manufactured by the Sutron Corporation. A radar sensor transmits radio energy to the water surface and multiplies the return of the energy to the sensor to compute the distance from the sensor to the water surface. An initial water level, entered after installation of the device, is used by the sensor to convert the distance between the sensor and the water surface into a water level reading (or stage). The Sutron RLR-0003-1 is weatherproof, and has a fully enclosed antenna and Federal Communications Commission part 15 approval. Any terminal emulation program can be used with SDI-12 commands to communicate with the sensor. Additional software, Sutron RLR Communicator Software, can be downloaded onto a PC computer from the Sutron Web site and used with the sensor to help identify whether objects in the radio path are inferring with the measurement. Selected manufacturer's specifications for the sensor are listed in table 1 (Sutron Corporation, 2013).

Table 1. Manufacturer's specifications for the Sutron RLR-0003-1 water level sensor.

[in., inches; ABS, American Bureau of Shipping; VDC, volts direct current; mA, milliampere; GHz, gigahertz; HPBW, half power band width; $\mathrm{ft}$, feet; ${ }^{\circ} \mathrm{C}$, degrees Celsius]

\begin{tabular}{ll}
\hline Feature & \multicolumn{1}{c}{ Specification } \\
\hline Housing dimensions & ABS plastic \\
Housing material & 6.85 pounds \\
Weight & SDI-12 and RS232 \\
Communication interfaces & $12 \mathrm{VDC}$ \\
Power Supply & $<0.9 \mathrm{~mA}$ \\
Current, standby & $<40 \mathrm{~mA}$ \\
Current, active & $6.6 \mathrm{GHz}$ pulse echo \\
Frequency & $\pm 16 \mathrm{degrees} \mathrm{HPBW}$ \\
Beam angle & $10 \mathrm{Hertz}$ \\
Sampling rate & 5 to $60 \mathrm{ft}$ \\
Range (distance to water) & $0.01 \mathrm{ft} 5-20 \mathrm{ft}, 0.05 \%$ reading $20-60 \mathrm{ft}$ \\
Accuracy & $0.01 \mathrm{ft}$ \\
Resolution & -40 to $60^{\circ} \mathrm{C}$ \\
Operating temperature range &
\end{tabular}

\footnotetext{
${ }^{1}$ (Sutron Corporation, 2013, p. 7).
} 


\section{Methods}

The Sutron RLR-0003-1 was evaluated by subjecting units to laboratory, SDI-12 communication, and field testing. Laboratory testing was conducted to evaluate the accuracy of the sensor over the manufacturer's specified operating temperature and distance to water ranges.

Laboratory results were compared to the manufacturer's accuracy specification for water level (table 1) and to the requirements of the USGS Office of Surface Water (OSW) policy requirement that water level sensors have a measurement uncertainty of no more than 0.01 foot (ft) or 0.20 percent of the indicated reading (USGS, 1996). SDI-12 communication testing was conducted to evaluate compliance with the SDI-12 communication protocol (SDI-12 Support Group, 2012). Field testing was conducted by the USGS Iowa Water Science Center at a gaging station to evaluate performance under field conditions and to compare sensor measurements with other continuous water level sensors.

\section{Temperature Testing}

Three radar sensors were installed in a walk-in environmental test chamber on a rack and pointed horizontally at a stationary target located about $8 \mathrm{ft}$ from the radars. A Design Analysis Associates (DAA) H377 temperature sensor was used to measure air temperature. Air temperature and radar distance measurements were sampled and logged by a DAA 500 XL logger every 5 minutes. Chamber temperatures were manually operated at various intervals and set at temperatures of $0,-40,20$, $-20,0,20,40,60,40$, and 20 (fig. 2). The initial distance measurement made at room temperature by a radar unit, the initial reading, was used as its reference distance. The difference between the reading and the initial reading was used to assess if the radar operated within accuracy specifications over a range of temperatures.

\section{Distance to Water Testing}

Three radar sensors were installed on a movable arm over still water in the HIF Hydraulic Laboratory. The vertical position of the arm was measured by a shaft encoder system. The water level was measured with a float and shaft encoder system. A DAA 500 XL Logger was used to sample and $\log$ the measurements made by the three radar sensors and the two encoders every 2.5 minutes. Two tests were conducted. Each test began with the arm located approximately $14 \mathrm{ft}$ above the water. The arm was lowered, raised, and lowered in 3 -ft increments from 14 to $5 \mathrm{ft}$ above the water (fig. 3). The reference distance to the water surface was computed from the arm encoder reading and the water level encoder reading (fig. 4). The initial distance measurement made by a radar at approximately $14 \mathrm{ft}$ above the water was used as its reference distance. The difference between the reference distance and the initial reference distance was used to compute the reference change in distance between the arm and the water surface - the reference difference. The difference between the reading and the initial reading was used to compute the change in distance between the radar and the water surface- the radar difference. The difference between the radar difference and the reference distance difference was used to assess whether the radar operated within accuracy specification over a range of air gaps. 


\section{SDI-12 Communication Testing}

Three units were checked for compliance with SDI-12 version 1.3 using a NR Systems SDI-12 verifier sold by NR Systems, Inc., with firmware version 1.6 and PC software version 5.1.0.4. The SDI12 verifier was connected to a PC and units were connected to the verifier and tested one at a time.

\section{Field Testing}

One unit, which was not used in the laboratory testing, was installed by the USGS Iowa Water Science Center at USGS streamgaging site 06808500, West Nishnabotna River at Randolph, Iowa. The drainage area for the site is 1,326 square miles. Instrumentation at the site included a bubbler water level system with a Sutron Accubar gage pressure sensor, and a DAA H3613 radar water level sensor. The data were collected from the instruments using standard USGS procedures. The data used for the field test were USGS provisional data collected from February 28 to July 11, 2013. The difference between the Sutron radar and the bubbler system and the difference between the Sutron radar and the DAA radar were used to compare the performance of the instruments. Periodic wire-weight gage readings were used to assess whether the Sutron radar, DAA radar, and bubbler system operated within accuracy requirements during the field test.

\section{Results}

\section{Temperature Testing}

The results from temperature testing in the walk-in chamber for the three units are shown in figures 5, 6, and 7. Only data that were collected when temperatures were changing less than 0.5 degree Celsius were plotted and checked for compliance to the accuracy specification. All units show minor effects from the temperatures, but do not have obvious trends. The average difference during the test was $-0.017,-0.012$, and $-0.012 \mathrm{ft}$ for the tested units. Summary statistics are listed in table 2 for the 898 data points collected and checked for compliance with accuracy specification for each sensor. The average measurements for the sensors are within the accuracy specification, except for serial number 1208558, which is marginally outside of the specification. Larger differences, which are outside of the manufacturer's accuracy specification, occur at several temperatures. Except for serial number 1208558, the differences are all within $0.05 \mathrm{ft}$. Serial number 1208558 had three measurements with differences of nearly $-0.15 \mathrm{ft}$.

Table 2. Summary statistics for the difference between the Sutron RLR-0003-1 radar reading and the initial Sutron RLR-0003-1 radar reading at a stationary target for temperatures within 0.5 degree Celsius of $-40,-20,0$, 20, 40, and 60 degrees Celsius for serial numbers 1208558, 1208559, and 1208560. Number of data points analyzed for each sensor was 898 .

\begin{tabular}{llll}
\multicolumn{1}{c}{ Summary statistic } & 1208558 & $\mathbf{1 2 0 8 5 5 9}$ & $\mathbf{1 2 0 8 5 6 0}$ \\
\hline & & Feet & \\
\hline Minimum & -0.15 & -0.05 & -0.05 \\
Maximum & 0.02 & 0.02 & 0.04 \\
Average & -0.017 & -0.012 & -0.012 \\
Standard deviation & 0.021 & 0.022 & 0.028 \\
\hline
\end{tabular}




\section{Distance to Water Testing}

The results for the distance to water testing are shown in figures 8,9 , and 10 . Two tests are shown plotted in a figure for each sensor along with the manufacturer's accuracy specification. The accuracy specification is also shown and data points are plotted with vertical error bars that represent the uncertainty of the reference difference. Plotted data met the accuracy specification if either the data point was within the accuracy limits or the vertical error bar crossed inside the accuracy limits. Most measurements were within the manufacturer's specified accuracy and the USGS accuracy requirements. Table 3 lists summary statistics for both tests, where the results were similar. Two of the three sensors tested were within manufacturer's accuracy specification and the USGS accuracy requirement when the uncertainty of the reference measurement was included. Serial number 1208559 had a small but noticeable trend with increasing air gap that the other two sensors did not have. A small, vertical misalignment of the sensor or a slightly out-of-specification sensor are potential explanations for the cause of the trend.

Table 3. Test 1 and test 2 summary statistics for the difference between the Sutron RLR-0003-1 radar difference with its initial reading and the reference difference with its initial reading.

\begin{tabular}{llllllll}
\hline \multicolumn{1}{c}{ Summary statistic } & \multicolumn{3}{c}{ Test 1 } & & \multicolumn{3}{c}{ Test 2 } \\
\hline & $\mathbf{1 2 0 8 5 5 8}$ & $\mathbf{1 2 0 8 5 5 9}$ & $\mathbf{1 2 0 8 5 6 0}$ & & $\mathbf{1 2 0 8 5 5 8}$ & $\mathbf{1 2 0 8 5 5 9}$ & $\mathbf{1 2 0 8 5 6 0}$ \\
\hline Minimum & -0.02 & -0.04 & -0.02 & & -0.02 & -0.03 & -0.02 \\
Maximum & 0.01 & 0.00 & 0.00 & & 0.00 & 0.00 & 0.00 \\
Average & -0.008 & -0.024 & 0.012 & & -0.009 & -0.016 & -0.013 \\
Standard deviation & 0.004 & 0.011 & 0.009 & & 0.005 & 0.010 & 0.008 \\
\hline
\end{tabular}

\section{SDI-12 Communication Testing}

The three sensors tested passed the NR Systems SDI-12 verifier test. The verifier test results are not a complete comprehensive test of the standard but are indicative of the sensor meeting the timing and command requirements of the standard.

\section{Field Testing}

The difference between the Sutron RLR-0003-1 and the bubbler system and the difference between the Sutron RLR-0003-1 and the DAA H3613 are plotted in figure 11. The differences shown in figure 11 are based on provisional data and are uncorrected. The differences are slightly larger with the bubbler system than for the DAA H3613 radar and range from approximately -0.20 to $0.10 \mathrm{ft}$. The average difference between the Sutron RLR-0003-1 and the bubbler system was $0.005 \mathrm{ft}$ and the average difference between the Sutron RLR-0003-1 and the DAA H3613 was -0.002 ft. The Sutron RLR-0003-1 had good agreement with the bubbler and with the DAA H3613 water level readings for the data analyzed, from February 28 to July 11, 2013. Figure 12 is a plot comparing the differences between the Sutron RLR-0003-1 radar and the wire-weight gage readings, and the differences between the DAA H3613 and the wire-weight gage readings with the USGS OSW accuracy requirements. The vertical error bars represent an estimate of the accuracy of the wire-weight gage readings of $0.01 \mathrm{ft}$. The 
Sutron RLR-0003-1 differences look similar in shape to the DAA H3613 differences shown in figure 11. The Sutron RLR-0003-1 meets the USGS accuracy requirements when compared to the wire-weight gage readings.

Table 4. Summary statistics for the differences between the Sutron RLR-0003-1 and either the Accubar bubbler system or the Design Analysis Associates (DAA) H3613 for the period from February 28 to July 11, 2013.

\begin{tabular}{lccc}
\hline \multicolumn{1}{c}{ Summary statistic } & $\begin{array}{c}\text { Bubbler system water level } \\
\text { reading } \\
\text { (feet) }\end{array}$ & $\begin{array}{c}\text { Difference with bubbler } \\
\text { system } \\
\text { (feet) }\end{array}$ & $\begin{array}{c}\text { Difference with DAA H3613 } \\
\text { (feet) }\end{array}$ \\
\hline Count & 12,736 & 12,736 & 12,744 \\
Minimum & 7.61 & -0.20 & -0.15 \\
Maximum & 14.29 & 0.10 & 0.06 \\
Average & 9.52 & -0.005 & -0.002 \\
Standard deviation & 1.53 & 0.038 & 0.018 \\
\hline
\end{tabular}

\section{Summary}

The Sutron RLR-0003-1 was evaluated by subjecting units to laboratory, SDI-12 communication, and field testing. Three Sutron RLR-0003-1 water level sensors were tested in laboratory conditions to evaluate the accuracy of the sensor over the manufacturer's specified operating temperature and distance to water ranges. Laboratory results were compared to the manufacturer's accuracy specification for water level and to the USGS Office of Surface Water (OSW) policy requirement that water level sensors have a measurement uncertainty of no more than $0.01 \mathrm{ft}$ or 0.20 percent of the indicated reading. Except for one sensor, the differences for the temperature testing were within $0.05 \mathrm{ft}$ and the average measurements for the sensors were within the manufacturer's accuracy specification. Two of the three sensors were within the manufacturer's specified accuracy and met the USGS accuracy requirements for the laboratory distance to water testing. Three units passed a basic SDI-12 communication compliance test. The field test was conducted from February 28 to July 11, 2013. Water level measurements made by using the Sutron RLR-0003-1 agreed well with those made by using the bubbler system and a DAA H3613 radar during field testing at USGS streamgaging site 06808500, West Nishnabotna River at Randolph, Iowa; the sensors also met the USGS accuracy requirements when compared to the wire-weight gage readings.

\section{Acknowledgments}

The authors gratefully acknowledge Joe Nania, Joe Gorman, and the personnel of the USGS Iowa Water Science Center who conducted the field study and supplied the data used in the field testing section of the report. 


\section{References Cited}

SDI-12 Support Group, 2013, SDI-12-A serial-digital interface standard for microprocessor-based sensors, version 1.3, 27 p., http://www.sdi-12.org/current\%20specification/SDI12_version1_3\%20January\%2026,\%202013.pdf.

Sutron Corporation, 2013, Radar level recorder RLR-0001-1 RLR-0003-1 operations and maintenance manual: Sutron Corporation, $67 \mathrm{p}$.

U.S. Geological Survey, 1996, Policy concerning accuracy of stage data: U.S. Geological Survey Office of Surface Water Technical Memorandum 96.05, unpaged, accessed September 5, 2013, at http://water.usgs.gov/admin/memo/SW/sw96.05.html.

For additional information regarding this publication, contact:

Chief, Hydrologic Instrumentation Facility

U.S. Geological Survey

Building 2101

Stennis Space Center, MS 39529

http://water.usgs.gov/hif/

Edited and prepared by:

USGS Science Publishing Network

Reston and Raleigh Publishing Service Centers 


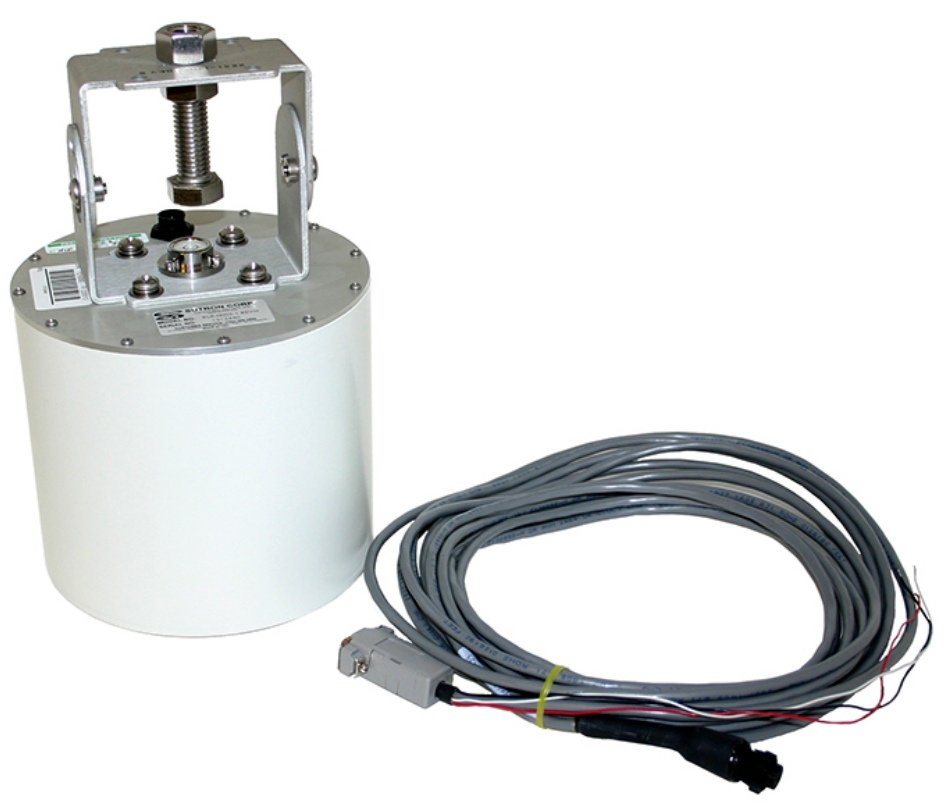

Figure 1. Photo of Sutron RLR-0003-1 water level sensor.

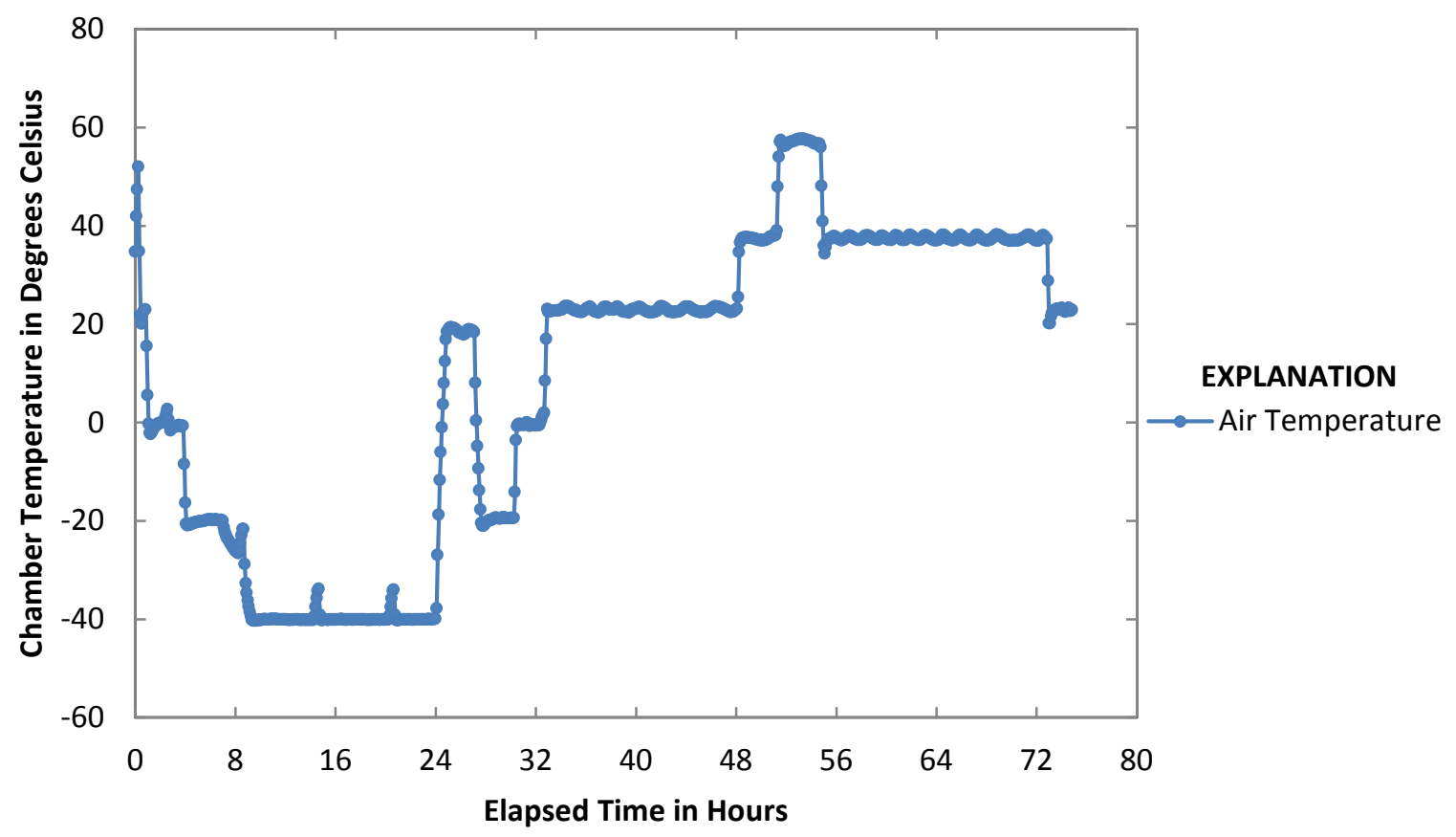

Figure 2. Temperatures applied during temperature testing for three Sutron RLR-0003-1 water level sensors. 


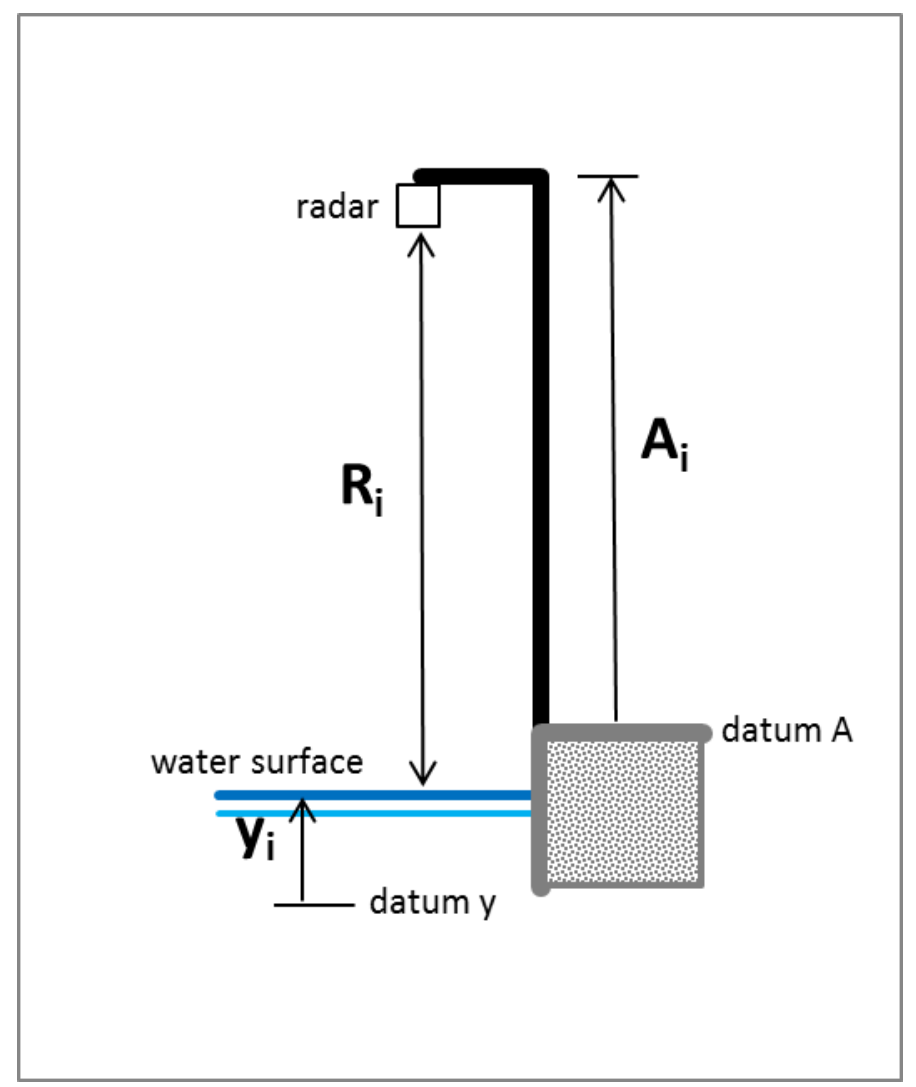

Figure 3. Definition sketch of hydraulic laboratory test measurement variables. $A_{i}$ is the position of the arm supporting the radar unit under test, $R_{i}$ is the radar measured air gap, and $y_{i}$ is the position of the water level during the test. The subscript $i$ denotes the ith measurement. 

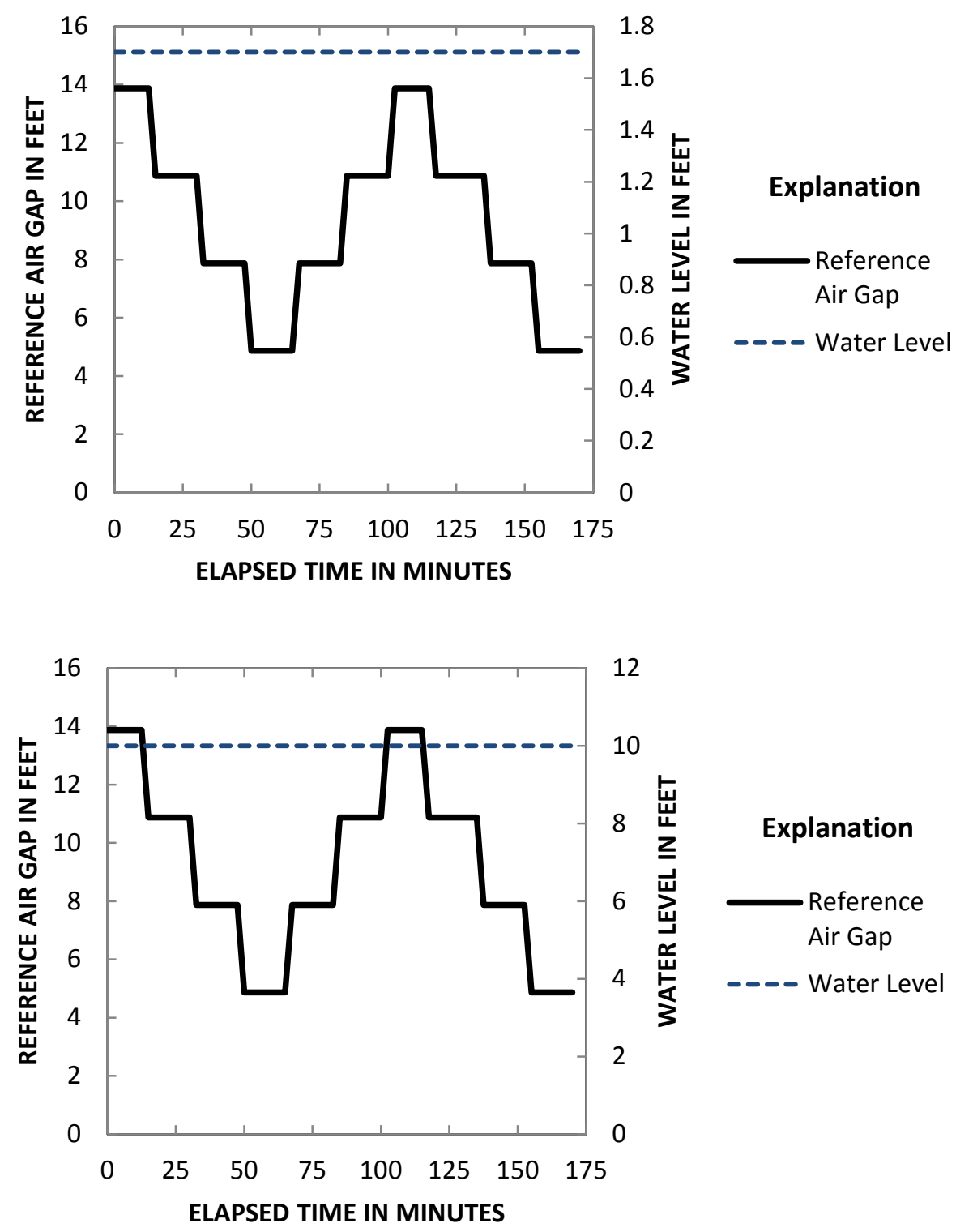

Figure 4. Air gap applied and water level measured during air gap testing for three Sutron RLR-0003-1 water level sensors. Top chart is for test 1 and bottom chart is for test 2 . 


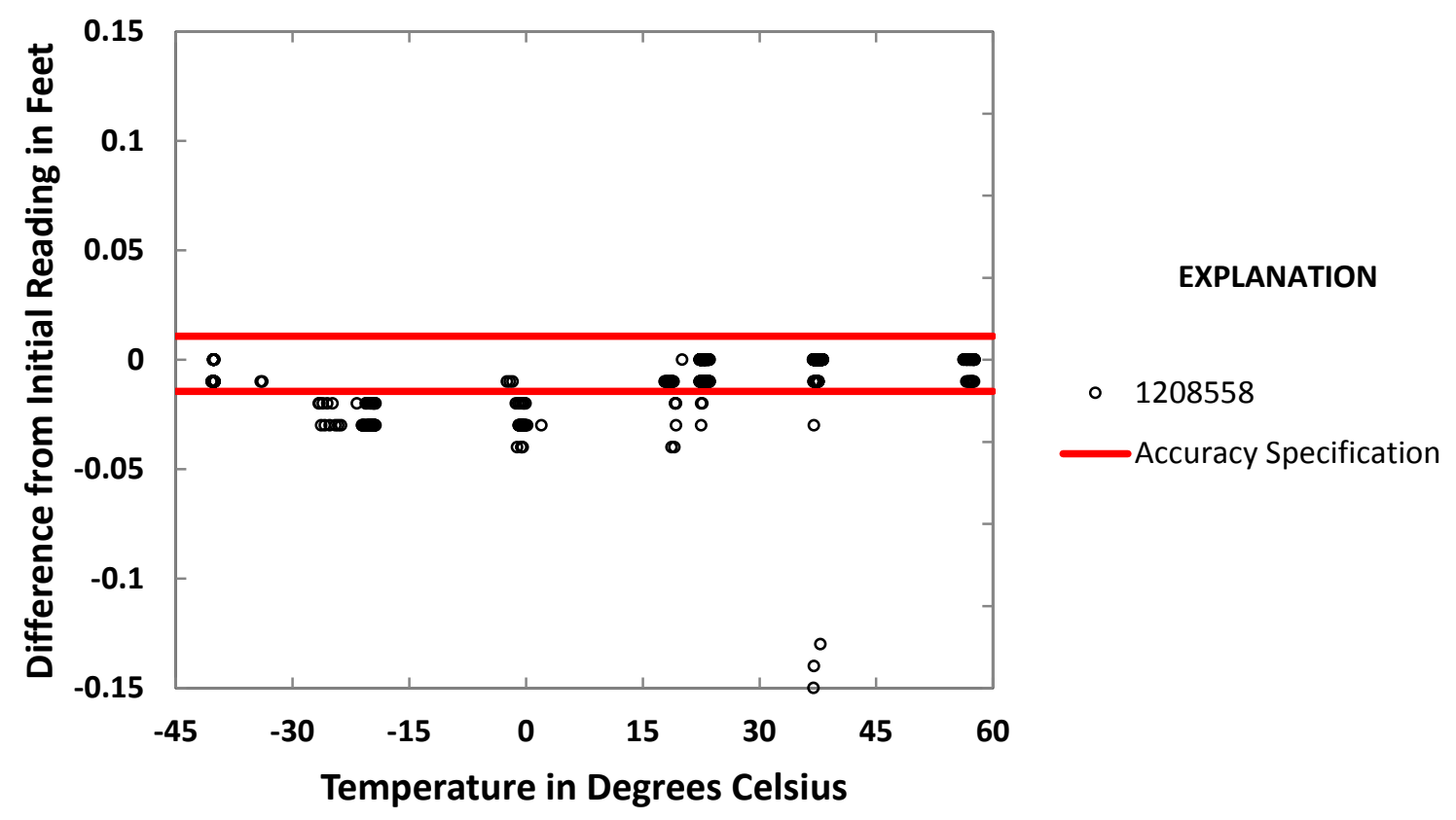

Figure 5. Difference between initial measured distance to a stationary target made by Sutron RLR-0003-1 (serial number 1208558) at room temperature and subsequent measurements made over temperatures from -40 to 60 degrees Celsius.

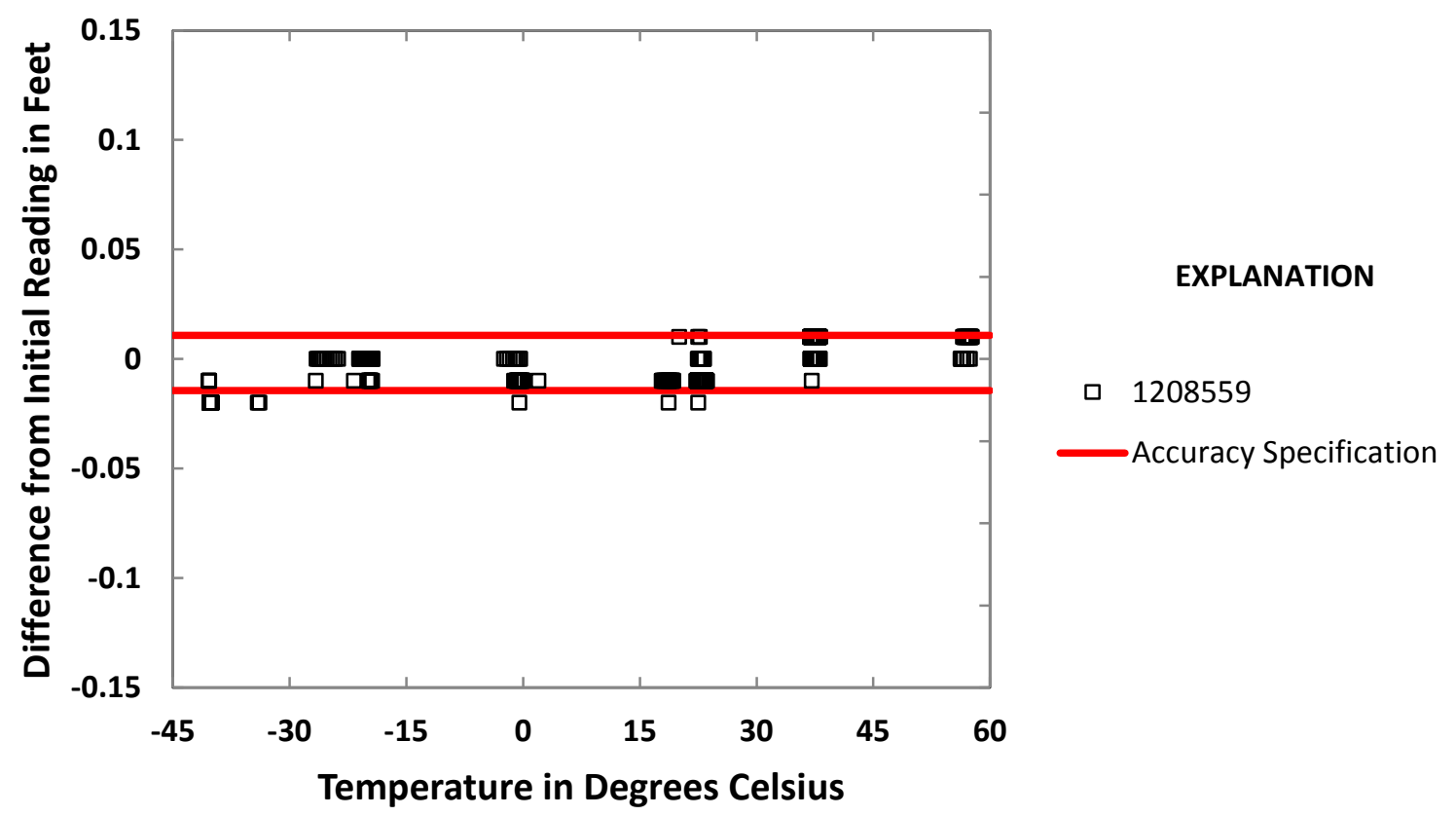

Figure 6. Difference between initial measured distance to a stationary target made by Sutron RLR-0003-1 (serial number 1208559) at room temperature and subsequent measurements made over temperatures from -40 to 60 degrees Celsius. 


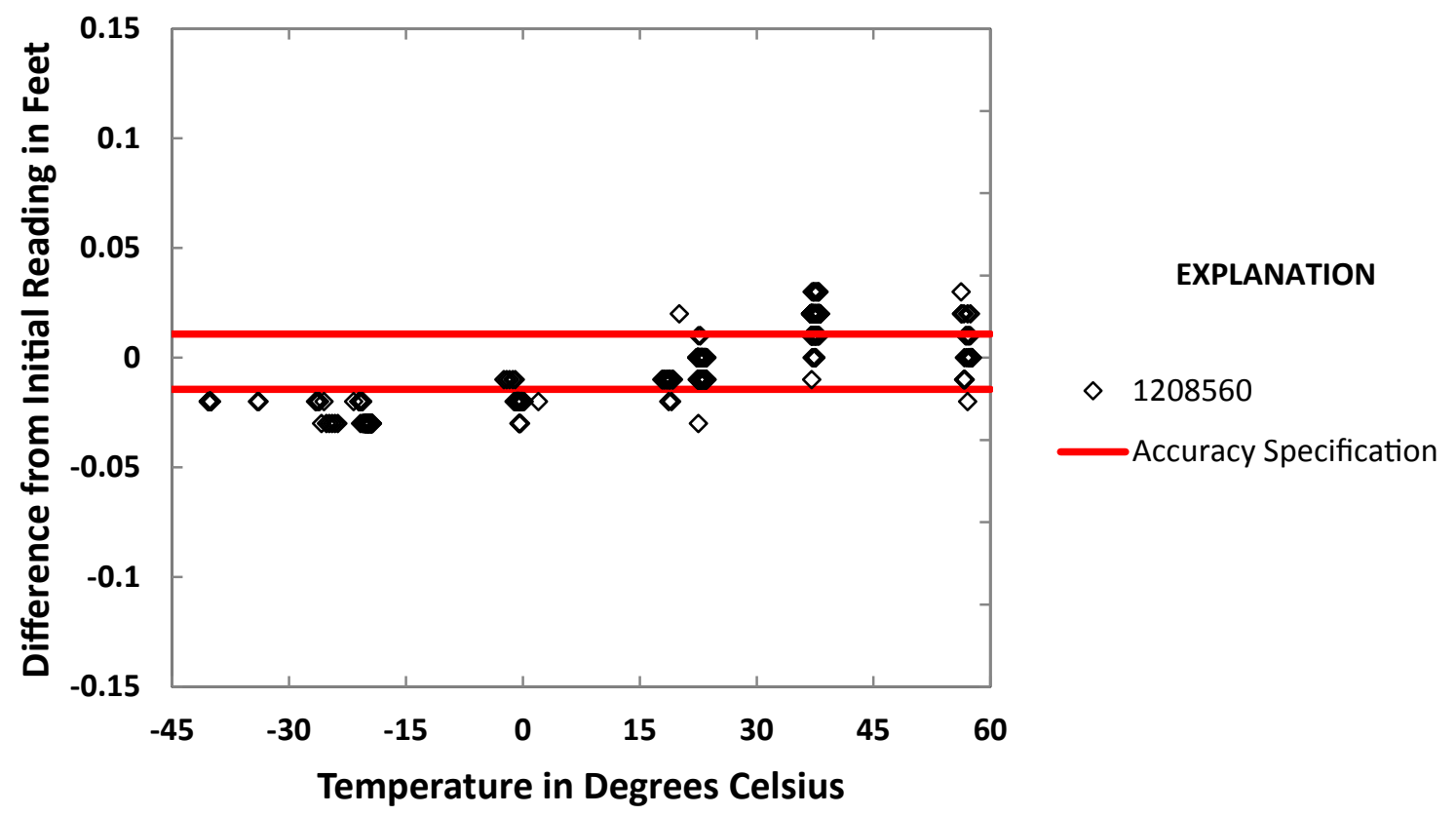

Figure 7. Difference between initial measured distance to a stationary target made by Sutron RLR-0003-1 (serial number 1208560) at room temperature and subsequent measurements made over temperatures from -40 to 60 degrees Celsius.

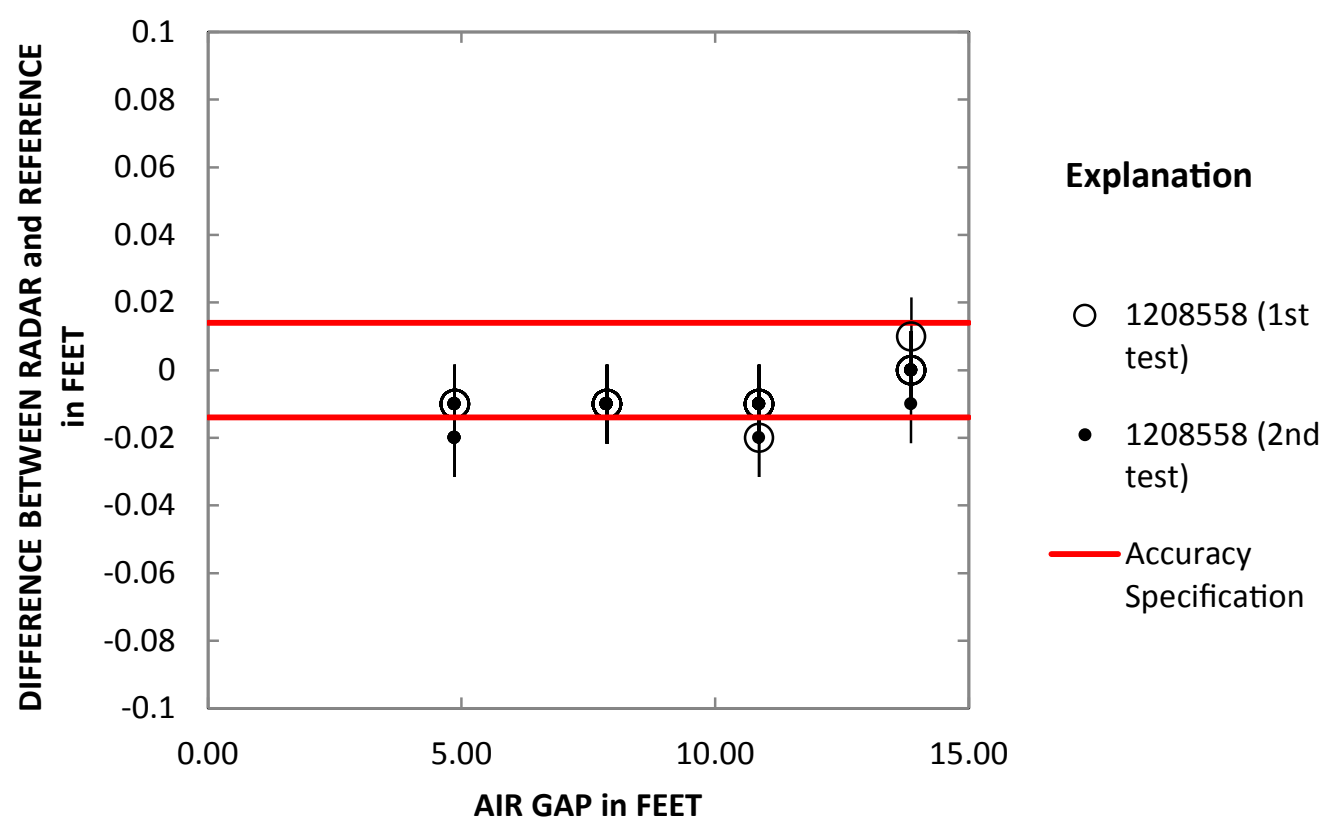

Figure 8. Difference between the change in air gaps (distance to water) measured by Sutron RLR-0003-1 (serial number 1208558) and measured by the references. The references were the arm position and water level measured by a float system. 


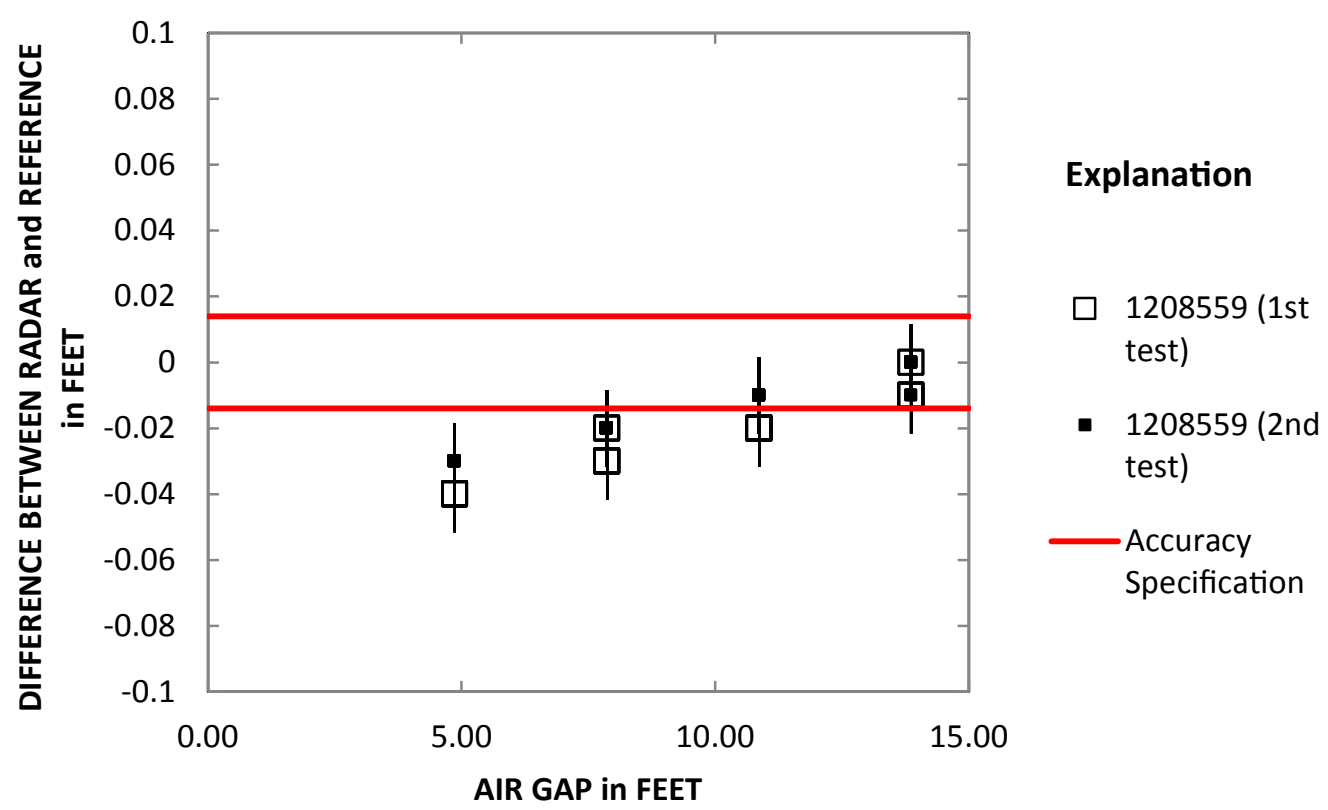

Figure 9. Difference between the change in air gaps (distance to water) measured by Sutron RLR-0003-1 (serial number 1208559) and measured by the references. The references were the arm position and water level measured by a float system.

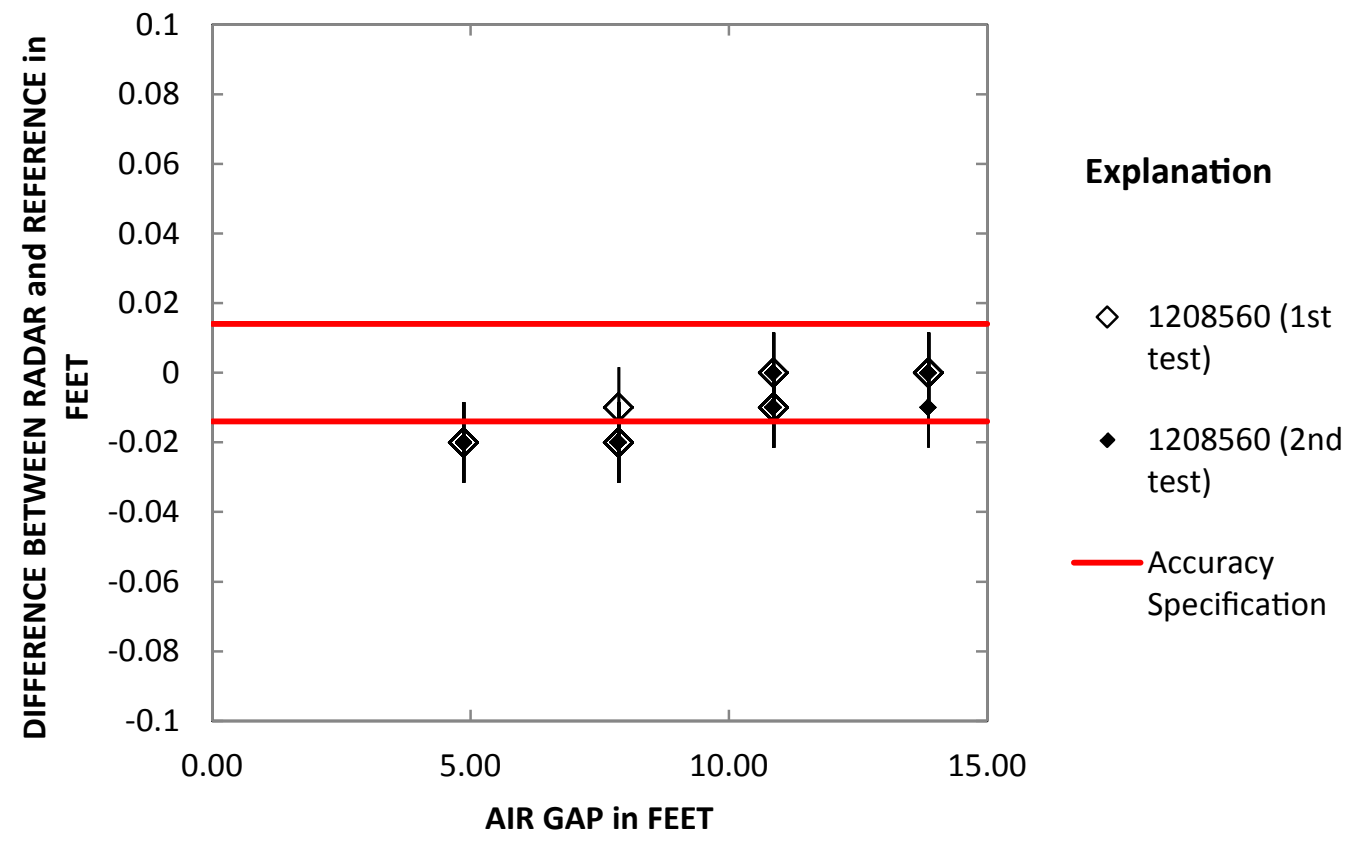

Figure 10. Difference between the change in air gaps (distance to water) measured by Sutron RLR-0003-1 (serial number 1208560) and measured by the references. The references were the arm position and water level measured by a float system. 

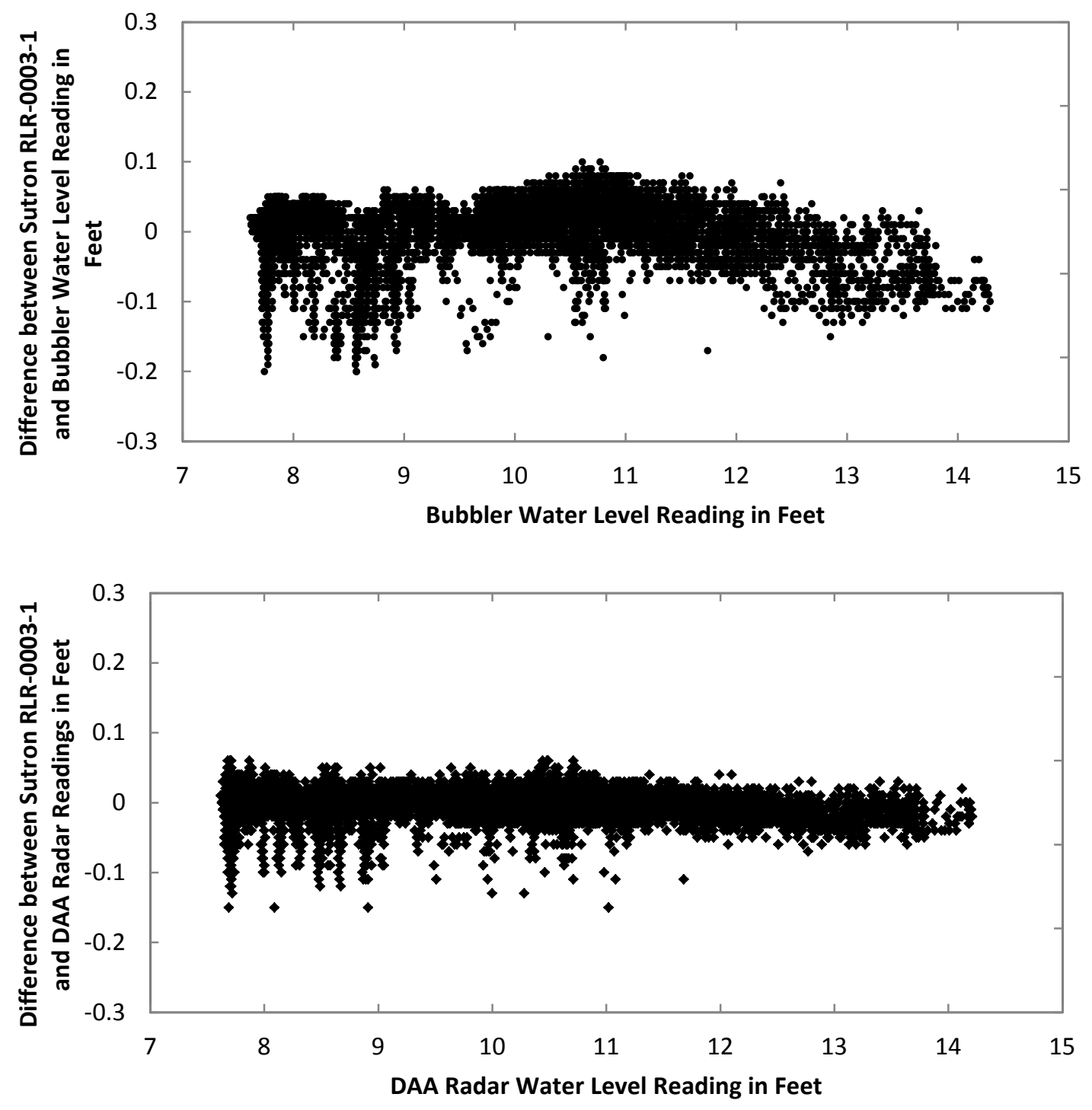

Figure 11. Differences between the Sutron RLR-0003-1 and the Sutron Accubar bubbler water level system readings (top chart) and differences between the Sutron RLR-0003-1 and the Design Analysis Associates H3613 water level radar (bottom chart) at U.S. Geological Survey streamgaging site 06808500 , for the period February 28, 2013 to July 11, 2013. 


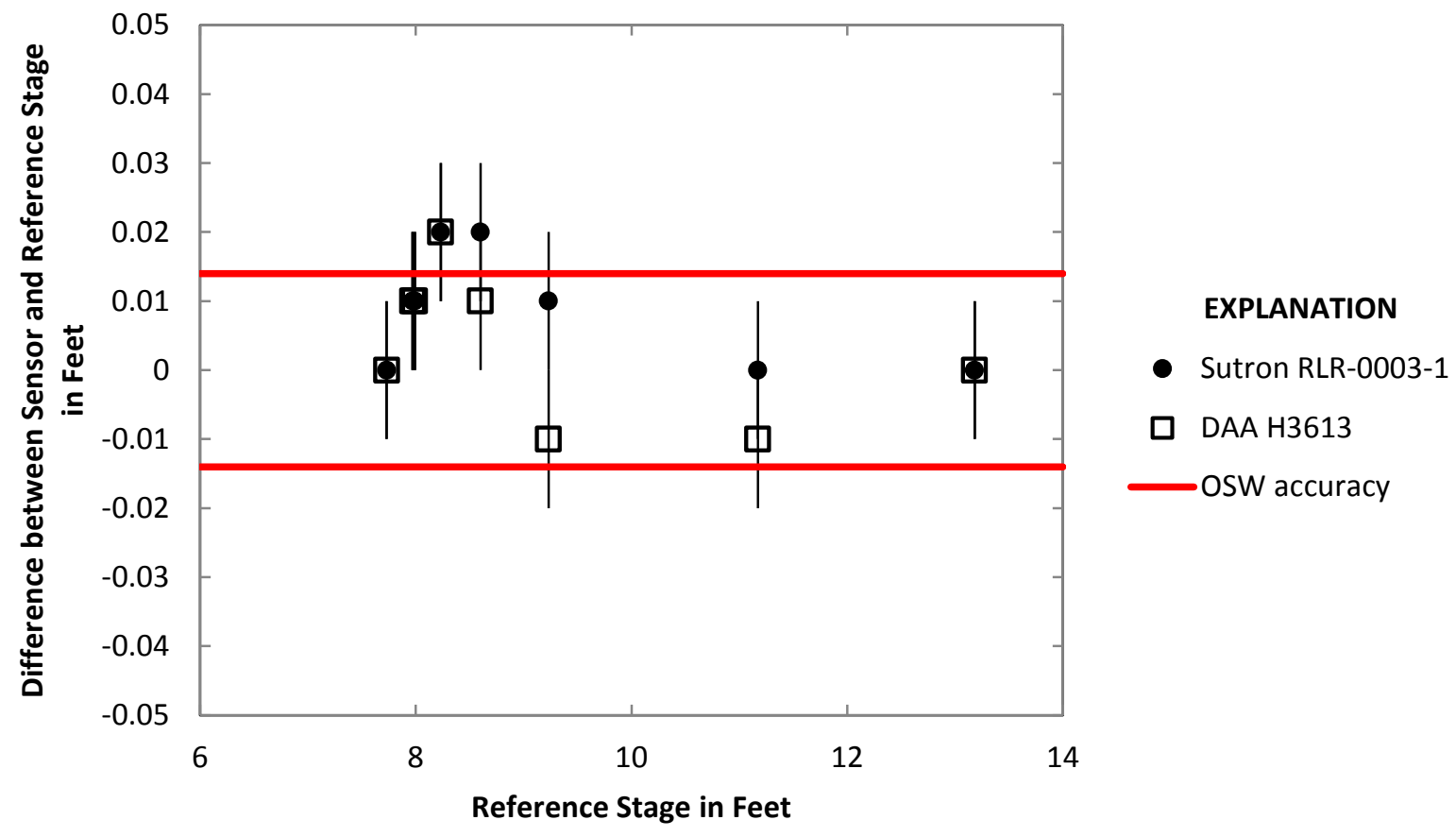

Figure 12. Comparison of the differences between the Sutron RLR-0003-1 radar, Design Analysis Associates (DAA) H3613 radar, and wire-weight gage readings plotted with U.S. Geological Survey Office of Surface Water (OSW) accuracy requirements. 
ISSN 2331-1258 (online)

http://dx.doi.org/10.3133/ofr20141217 